\title{
METHOD FOR NITRATE DETERMINATION IN WATER IN THE PRESENCE OF NITRITE
}

\author{
Maria Sandu ${ }^{\mathrm{a}^{*}}$, Tudor Lupascu ${ }^{\mathrm{b}}$, Anatol Tarita ${ }^{\mathrm{a}}$, Tatiana Goreacioc ${ }^{\mathrm{a}}$, \\ Sergiu Turcan ${ }^{\mathrm{a}}$, Elena Mosanu ${ }^{\mathrm{a}}$ \\ ${ }^{a}$ Institute of Ecology and Geography, A.S.M., 1, Academiei str., Chisinau MD-2028, Republic of Moldova \\ ${ }^{b}$ Institute of Chemistry, A.S.M., 3, Academiei str., Chisinau MD-2028, Republic of Moldova \\ *e-mail: sandu_mr@yahoo.com; phone: (+373 22) 73 15 50; 721774
}

\begin{abstract}
The study relates to determination of nitrate in presence of nitrite in water and can be used in the quality monitoring of natural water (surface and groundwater), drinking water, water from fish farms and public aquaria where autonomous filters is used. The nature and quantity of reagents used have insignificant impact on natural waters and sewages. According to the investigation, the method includes the removal of nitrite from the solution/water with sulfaminic acid, the nitrate ion reduction to nitrite using a reducing mixture that contains $\mathrm{Na}_{2} \mathrm{SO}_{4}$ and zinc dust in ratio of 100:5 and determining the nitrite with the Griess reagent.
\end{abstract}

Keywords: water, nitrate determination, nitrites, sulfaminic acid, Griess reagent, reducing mixture.

\section{Introduction}

Water quality in wells and often in centralized distribution systems, almost on all over the country territory don't correspond to the standard for drinking water even after nitrate content. Analysis of groundwater quality monitoring results conducted by the Agency for Geology and Mineral Resources of the Republic of Moldova (AGRM) shows that the most artesian water contains ammonium ions, nitrate and nitrite in considerable amounts, sometimes exceeding the maximum allowable concentration (MAC) for drinking purposes. In Ialoveni district, for example, about $32 \%$ of the wells contain $69-280 \mathrm{mg} / \mathrm{dm}^{3} \mathrm{NO}_{3}^{-[}[1]$.

The process of nitrification in natural waters has mandatory stage the appearance of nitrite content of which in surface waters in Moldova ranges from $0-0.4 \mathrm{mg} / \mathrm{dm}^{3}$ to tens of $\mathrm{mg} / \mathrm{dm}^{3}$ in small rivers water downstream of sewage discharges, insufficiently treated in biological purification plants type. During of 2002-2004 years, in the river Bac downstream of Chisinau city it was registered $1.2-16.8 \mathrm{mg} / \mathrm{dm}^{3} \mathrm{NO}_{2}^{-}$; in river Lunga (village Lunga) - of 3.6 till 12.6 $\mathrm{mg} / \mathrm{dm}^{3} \mathrm{NO}_{2}^{-}$and nitrates content ranged from 0.8 to $18.7 \mathrm{mg} / \mathrm{dm}^{3}[2]$.

Thus the assessment of nitrate and nitrite content $\left(\mathrm{NO}_{3}^{-}\right.$in the presence of $\left.\mathrm{NO}_{2}^{-}\right)$in the aquatic medium, performed by analytical services for monitoring of natural, drinking, waste waters, food and soil is of real importance.

This highlights the necessity to develop the simple methods for determining nitrate in presence of nitrite in water and to identify those which are not presented in the normatives for drinking water.

\section{Experimental Apparatus}

Visible spectrophotometer (Model HACH) with $2 \mathrm{~cm}$ matching cells was used for the absorbance measurements. A pH-ionometer I-120.1 was used for $\mathrm{pH}$ measure.

\section{Reagents and Solutions}

All chemicals used were of analytical reagent grade, and double distilled water was used in the preparation of all solutions for the experiments.

Nitrite solution $\left(20 \mathrm{mg} / \mathrm{cm}^{3}\right)$ was prepared by dissolving $3.0 \mathrm{~g}$ sodium nitrite in water and diluting to $100 \mathrm{~cm}^{3}$. Nitrate solution $\left(1000 \mathrm{mg} / \mathrm{dm}^{3}\right)$ was prepared by dissolving $1.371 \mathrm{~g}$ sodium nitrate in water and diluting to $1000 \mathrm{~cm}^{3}$. Working standard nitrate solutions were prepared by appropriate dilution. Sulfaminic acid solution was used of $3 \mathrm{mg} /$ $\mathrm{cm}^{3}\left(0.3 \mathrm{~g}\right.$ in $\left.100 \mathrm{~cm}^{3}\right)$ and Griess reactive - of $3 \%\left(3 \mathrm{~g}\right.$ in $\left.100 \mathrm{~cm}^{3}\right)$. To adjust the value of $\mathrm{pH}$ the solutions of $\mathrm{HCl}$ and $\mathrm{NaOH}\left(0.1 \mathrm{~mol} / \mathrm{dm}^{3}\right)$ were used.

\section{Results and discussion}

Allowable levels for drinking water, which are binding in the Republic of Moldova by Government Decision no. 934 of 15.08 .2007 is of $50 \mathrm{mg} / \mathrm{dm}^{3}$ for nitrate and $0.5 \mathrm{mg} / \mathrm{dm}^{3}$ for nitrite. Thus the problem of nitrate and nitrite monitoring in waters intended for human consumption (drinking water, water for foods preparation etc.) is in attention of specialized institutions [3].

There are various methods for nitrate and nitrite determining, including spectrometric, fluorometric, luminescent, electrophoretic, electrochemical and chromatographic.

Presented at the International Conference dedicated to the $55^{\text {th }}$ anniversary from the foundation of the Institute of Chemistry of the Academy of Sciences of Moldova 
To determine nitrites it is widely used the photometric method with Griess reagent proposed in 1879 year [4] with sensitivity of $0.001 \mathrm{mmol} / \mathrm{dm}^{3}$. The sensitivity, simplicity of the method, the accessibility of Griess reagent permits to use them for nitrate determination after its reduction to nitrite, but it is necessary to remove nitrites present in the water/solution.

There is also the method for the determination of $\mathrm{NO}_{3}^{-}$ions with sulfosalicylic acid, but the process is influenced by the presence of more than $2 \mathrm{mg} / \mathrm{dm}^{3}$ of nitrites and consists of several steps which hinder the analytical work (boiling, evaporation, dissolving the shift quantity of the solution in the other vessel, etc.) [5].

Determination of nitrates may be carried out also by reaction with diphenylamine, but in the presence of nitrite method can not be applied, since they formed with diphenylamine colour compound [6].

Widely for nitrate determination there are used methods based on the principle of nitrate to nitrite preventive reduction, those latter being determined by Griess reaction. The reduction $\mathrm{NO}_{3}{ }^{-} \rightarrow \mathrm{NO}_{2}^{-}$is carried out by cadmium column [7-9], vanadium compounds $(+3$ and +4$)$ [10], zinc and manganese sulphate $[11,12]$. In all cases nitrites influence the process. Since the determination of nitrate in the presence of nitrites has limitations [13], it has been proposed solution to remove preventative nitrite with sodium azide in the reduction system $\mathrm{Zn}$-Fe (III)-Ferozin (sodium salt of $\mathrm{p}$, $\mathrm{p}^{\prime}$ disulphonic hydrate, 3 - (2-pyridyl) -5,6-diphenyl-1,2,4-triazine acid) [14].

\section{Determination of nitrate in presence of nitrite using the existing methods has the following disadvantages:}

- For analysis of several samples of water, there are required simultaneously multiple columns with cadmium. A large amount of metallic $\mathrm{Cd}$ and cadmium column passes through several stages of preparation (Cd metal preparation, washing the column before and after the reduction of $\mathrm{NO}_{3}^{-}$ions), that takes time. Cadmium is a relatively non-specific reductant and methods of its utilization are inefficient at lower concentrations of nitrate [15].

- Cadmium is a toxic element with a low limit of exhaust in wastewater treatment system and the environment $\left(0.1 \mathrm{mg} / \mathrm{dm}^{3}\right)$. In some countries, the production and cross-border movement of cadmium and its compounds are prohibited by law.

- In the case of vanadium, its compounds $(+3$ and +4 forms $)$ are reduced by magnesium metal in an acid medium, and the solution is kept under argon, into the same flask.

- Vanadium is included in the families and groups of substances which have a deleterious effect on the aquatic medium [16].

- The disadvantage of the process of nitrite removal with sodium azide is that the reagent is toxic, including discharge into the natural water and sodium salt of $\mathrm{p}, \mathrm{p}^{\prime}$ - disulphonic acid hydrate 3 - (2- pyridyl) -5.6 - diphenyl - 1,2,4 - triazine acid is a shortage reagent and it is not known impact on the environment.

Pre-treatment of water with sulfaminic acid (ASA) allows the removal of the nitrite and nitrosating agents before nitrates determination after their reduction to nitrite [5, 17].

Sulfaminic acid reacts with nitrite and forms free nitrogen, water and sulphuric acid:

$$
\mathrm{NH}_{2} \mathrm{SO}_{3} \mathrm{H}+\mathrm{HNO}_{2} \rightarrow \mathrm{N}_{2}+\mathrm{H}_{2} \mathrm{SO}_{4}+\mathrm{H}_{2} \mathrm{O} .
$$

The advantage of sulfaminic acid using consists in economy, efficiency and ease of use.

In the passport of Security according Document 1907/2006/EC, art. 31(24/09/2013, version 3) it is mentioned that sulfaminic acid has insignificant effect in waste water canalization.

There are international standard methods taken by the Republic of Moldova for separate nitrates and nitrites determination in the water $[18,19]$. But it is missing the standard for determining of nitrate in presence of nitrite.

The purpose of the present study is to develop a simple method for determination of nitrate in the presence of nitrite in aqueous solutions and natural waters using a reducing mixture $\mathrm{Na}_{2} \mathrm{SO}_{4}: \mathrm{Zn}$, Griess reagent and sulfaminic acid.

The most appropriate method to determine nitrates in the presence of nitrites is the process for removal of nitrite from the solution/water using sulfaminic acid [5] and the process of nitrate to nitrite reduction with a reducing mixture $\mathrm{MnSO}_{4}: \mathrm{Zn}=100: 2$ and determination of formed $\mathrm{NO}_{2}^{-}$ions with Griess reagent [12]. The disadvantage of the method is the use of $\mathrm{MnSO}_{4}\left(300 \mathrm{mg}\right.$ for a sample), which is more expensive, and $\mathrm{Mn}^{2+}$ has a low permissible content to discharge into canalization system $\left(1 \mathrm{mg} / \mathrm{dm}^{3}\right)$ and the environment.

Sodium sulphate, proposed as reducing mixture component $\mathrm{Na}_{2} \mathrm{SO}_{4}: \mathrm{Zn}=100: 5$, is used in amounts of 2.5 times lower (120 mg for a sample) as $\mathrm{MnSO}_{4}$, which is about two times cheaper and has a much higher discharge into waste water system or the environment $\left(200 \mathrm{mg} / \mathrm{dm}^{3}\right)$.

The process is characterised by simplicity, given the opportunity to perform simultaneous analysis of large numbers of samples, using efficient and accessible reagents that have a minimal negative effect on wastewater treatment technology and the environment to their discharge into drains and the environment. Zinc dust, which is not consumed in the reaction, is collected, washed with distilled water, dried and subsequently used for obtaining the reducing mixture $\mathrm{Na}_{2} \mathrm{SO}_{4}: \mathrm{Zn}$.

The process consists in nitrite removal from natural waters and aqueous solutions to free nitrogen $\left(\mathrm{N}_{2}\right)$ by ASA $\left(\mathrm{NH}_{2} \mathrm{SO}_{3} \mathrm{H}+\mathrm{HNO}_{2} \rightarrow \mathrm{H}_{2} \mathrm{O}+\mathrm{N}_{2}+\mathrm{H}_{2} \mathrm{SO}_{4}\right)$, reduction of nitrate to nitrite with a mixture consisting of sodium sulphate and zinc powder in ratio of components $\mathrm{Na}_{2} \mathrm{SO}_{4}: \mathrm{Zn}=100: 5$. The chemistry of the reaction is in the process of reducing 
of nitrates $\mathrm{Zn}+\mathrm{NO}_{3}^{-}=\mathrm{NO}_{2}^{-}+\mathrm{Zn}^{2+}\left(1 \mathrm{mg} \mathrm{NO}_{3}^{-}\right.$is reduced by $1.08 \mathrm{mg}$ of metallic $\left.\mathrm{Zn}\right)$. The reduction of nitrates from $10 \mathrm{~cm}^{3}$ water/solution with concentration of $0.2-10 \mathrm{mg} / \mathrm{dm}^{3}$ consumed about $0.005-0.1 \mathrm{mg}$ of zinc. Nitrite formed in the reaction is determined by Griess reagent widely used in the present and enough sensitive for routine use:

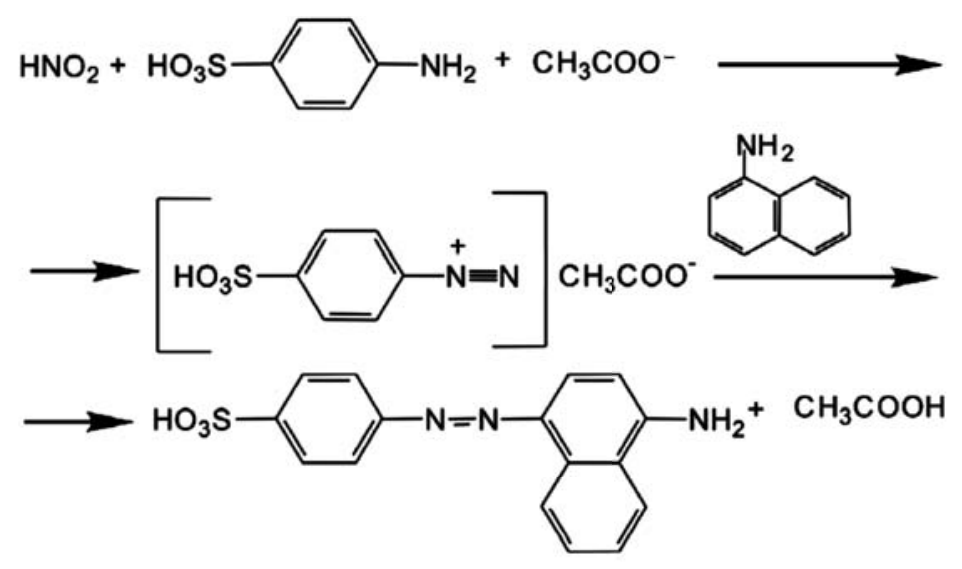

To establish the conditions for removal of nitrite it was estimated the quantity of sulfaminic acid, the time and the value of $\mathrm{pH}$ necessary for nitrite transformation to free nitrogen. In order to elucidate the conditions for reduction of nitrates in water it was evaluated the quantity of reducing mixture, the time of there contact with nitrate ions and those for formed nitrite with Griess reagent. (Figure 1).

The results indicate that the removal of nitrite from sulfaminic acid solution takes place during of 25-30 minutes (Figure 2).

Obtained data reveal that $3 \mathrm{mg}$ of sulfaminic acid remove nitrite in solution containing of $20 \mathrm{mg} / \mathrm{dm}^{3} \mathrm{NO}_{2}$

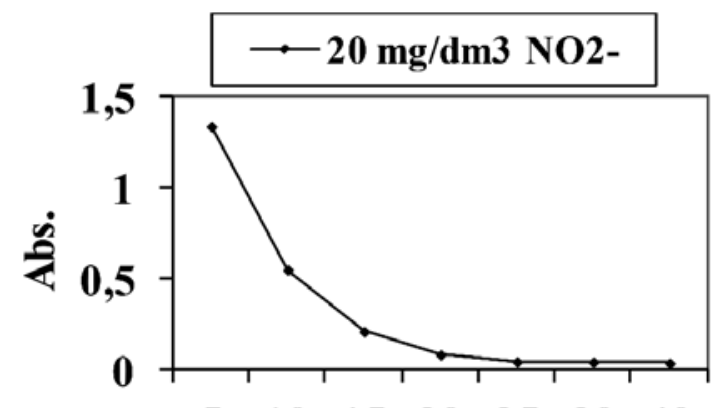

Figure 1. The amount of $\mathrm{NO}_{2}^{-}$ion oxidation with sulfaminic acid by adding reduction mixture $\mathrm{Na}_{2} \mathrm{SO}_{4}: \mathrm{Zn}=100: 5$.

$\begin{array}{lllllll}5 & 10 & 15 & 20 & 25 & 30 & 40\end{array}$

minutes

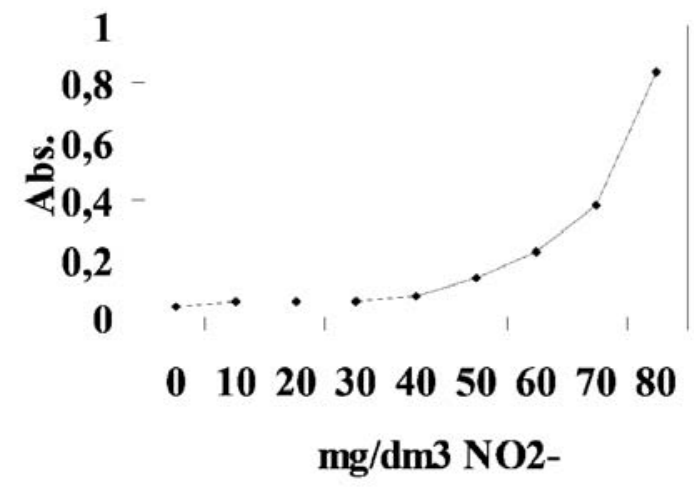

Figure 2. The absorbance of the solution containing $20 \mathrm{mg} / \mathrm{dm}^{3}$ of $\mathrm{NO}_{2}^{-}$contacted with $3 \mathrm{mg}$ of ASA in the conditions of $\mathrm{NO}_{3}^{-}$ions determination.

Thus, by adding $3 \mathrm{mg}$ of sulfaminic acid, to $10 \mathrm{~cm}^{3}$ of solution, it can be determined nitrate (less $\left.10 \mathrm{mg} / \mathrm{dm}^{3}\right) \mathrm{in}$ the presence of nitrites (less $20 \mathrm{mg} / \mathrm{dm}^{3}$ ). 
The effect of nitrate to nitrite reduction is optimal by using $120 \mathrm{mg}$ of reduction mixture for one sample (Figure 3 ). The effect of nitrite removal from solution before nitrates determination is optimal at $\mathrm{pH} 1-2.5$ (Figure 4). The results show that reduction mixture $(120 \mathrm{mg})$ convert nitrate to nitrite in the solution during of 10 minutes (Figure 5).

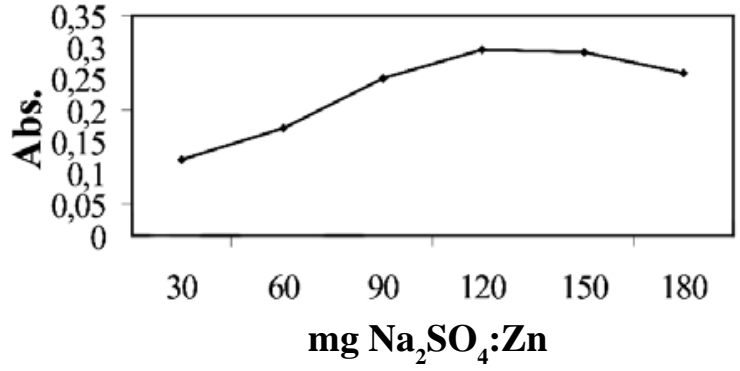

Figure 3. The absorbance of solutions containing $20 \mathrm{mg} / \mathrm{dm}^{3}$ of $\mathrm{NO}_{2}^{-}$and $2 \mathrm{mg} / \mathrm{dm}^{3}$ of $\mathrm{NO}_{3}^{-}$ions contacted with $3 \mathrm{mg}$ of sulfaminic acid in function on the amount of reduction mixture.

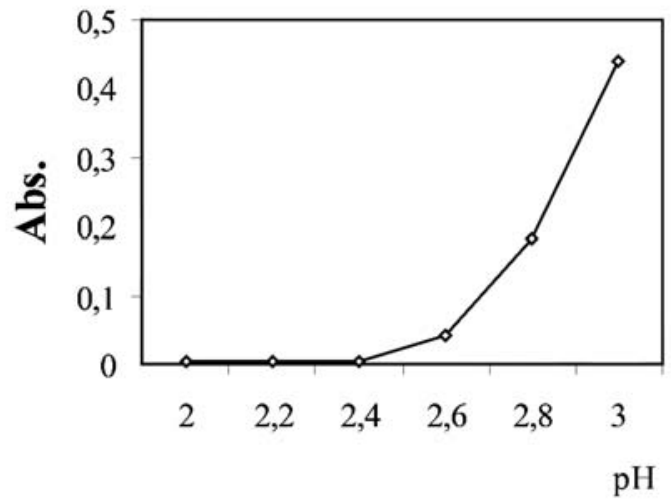

Figure 4. Solutions absorbance witch contain nitrites $\left(20 \mathrm{mg} / \mathrm{dm}^{3}\right)$ and sulfaminic acid $(3 \mathrm{mg})$ in dependence on the $\mathrm{pH}$.

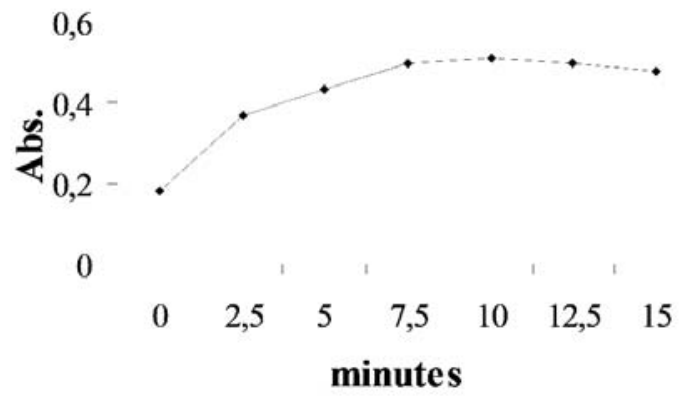

Figure 5. Time dependence of absorbance for $\mathrm{NO}_{3}^{-}$ions reduction with mixture $\mathrm{Na}_{2} \mathrm{SO}_{4} \mathrm{Zn}=100: 5$ in the presence of nitrite and ASA.

So, it was obtained the following method for nitrate determination in presence of nitrite.

\section{The method for nitrate determination in presence of nitrite}

In the calibrated flask of $10 \mathrm{~cm}^{3}$, an aliquot of solution for analysis is used $\left(0.1-10 \mathrm{mg} / \mathrm{dm}^{3} \mathrm{of} \mathrm{NO}_{3}{ }^{-}\right.$and not more than $20 \mathrm{mg} / \mathrm{dm}^{3}$ of $\mathrm{NO}_{2}^{-}$), then $0.3 \mathrm{~cm}^{3}$ of sulfaminic acid solution with a concentration of $10000 \mathrm{mg} / \mathrm{dm}^{3}(3 \mathrm{mg} / \mathrm{sample})$ is added. The volume is bringing up to $10 \mathrm{~cm}^{3}$ with distilled water, stirred after each 5 minutes during of 30 minutes $(6$ times). Then (after 30 minutes) $120 \mathrm{mg}$ of reduction mixture $\mathrm{Na}_{2} \mathrm{SO}_{4}: \mathrm{Zn}=100: 5$ is added and is stirred for 3 times during of $10 \mathrm{~min}$. After the nitrate reduction period $(10 \mathrm{~min})$ in the solution is poured $1 \mathrm{~cm}^{3}$ of $3 \%$ solution of Griess reagent, 30 minutes later the absorbance of the red solutions is measured at the wavelength of $520 \mathrm{~nm}$. As a comparison it is use a solution containing reagents used properly: to $9.7 \mathrm{~cm}^{3}$ of distilled water, $0.3 \mathrm{~cm}^{3}$ sulfaminic acid and $1 \mathrm{~cm}^{3}$ of $3 \%$ Griess reagent to meet stages and time mentioned.

The calibration curve is obtained using a standard solution of $\mathrm{NaNO}_{3}$ with concentration of $\mathrm{NO}_{3}$ - ions from 0.5 to $10 \mathrm{mg} / \mathrm{dm}^{3}$, adding reagents, and required time following the steps described in the method (Figure 6).

Nitrate and nitrite standard solutions are stored in a refrigerator at $4^{\circ} \mathrm{C}$.

\section{Result of the study and novelty criterion consists of the following:}

1. In the process of nitrates determination in the presence of nitrites into aqueous solutions and natural waters the sulfaminic acid is used for removal of the nitrites and creation of appropriate $\mathrm{pH}$ of the reaction, reduction mixture consisting in chemical available substances $\left(\mathrm{Na}_{2} \mathrm{SO}_{4}\right.$ and $\mathrm{Zn}$ powder in the ratio of 100:5) for the reduction of nitrates to nitrites and Griess reagents for the determination of formed nitrites. 
2. The result of proposed method consists in minimizing of analysis cost and use of efficient reagents which have a minimal negative effect on wastewater treatment technology and the environment as a result of discharge into drains or the environment.

3. The procedure has a sensitivity of $0.1 \mathrm{mg} / \mathrm{dm}^{3} \mathrm{NO}_{3}^{-}$in the presence of $20 \mathrm{mg} / \mathrm{dm}^{3}$ of $\mathrm{NO}_{2}{ }^{-}$ions. Relative error of the method is from 0.21 to $1.5 \%$ and relative standard deviation - within the limits of $0.2-3.0 \%$.

4. The removal of nitrite with ASA ensures the value of $\mathrm{pH}$ essential for process, the $\mathrm{Na}_{2} \mathrm{SO}_{4}-$ stable ionic strength in solutions with the effectiveness determination of nitrate in the presence of nitrite in ratio $\mathrm{NO}_{2}^{-}: \mathrm{NO}_{3}^{-}=20:(0.1-10)$, by using a reducing mixture $\mathrm{Na}_{2} \mathrm{SO}_{4}: \mathrm{Zn}=100: 5$ and Griess reagent, reagents having a little impact on waste water sewage and the environment.

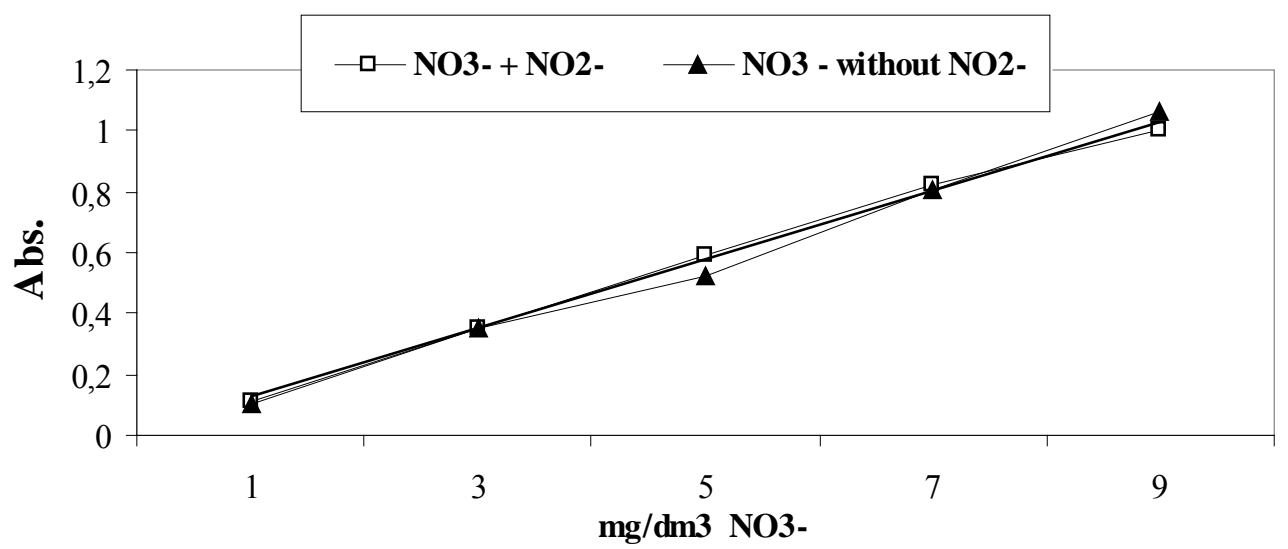

Figure 6. The calibration curve for nitrates determination in the absence $\left(y=0.2362 x-0.3748, R^{2}=0.9955\right)$ and presence $\left(y=0.2249 x-0.3216, R^{2}=0.9975\right)$ of nitrites.

The solution which contains $1 \mathrm{mg} / \mathrm{dm}^{3}\left(0.016 \mathrm{~mol} / \mathrm{dm}^{3}\right)$ in $2 \mathrm{~cm}$ cuvette has a media absorbance of $0.114 \pm 0.010$ at $520 \mathrm{~nm}$. So the molar extinction coefficient is of $3.56 \pm 0.09 \cdot 10^{3}\left(\mathrm{~cm}^{-1} \mathrm{M}^{-1}\right)$ and the sensibility of $\mathrm{NO}_{3}^{-}$determination reaction - of $0.1 \mathrm{mg} / \mathrm{dm}^{3}$, relative standard deviation - within the limits of $0.2-3.0 \%$.

A number of ions potentially present in natural, drinking waters, in public aquariums and fish farms do not affect the determination of nitrate in presence of nitrite under the conditions of the present method (Table 1).

Table 1

Ions that not affect nitrate determination in the presence of nitrite.

\begin{tabular}{cc}
\hline Ions & The tolerance $\left(\mathrm{mg} / \mathrm{dm}^{3}\right)$ \\
\hline $\mathrm{Al}^{3+}$ & 150 \\
$\mathrm{Ba}^{2+}$ & 100 \\
$\mathrm{Ca}^{2+}$ & 300 \\
$\mathrm{Cd}^{2+}$ & 1000 \\
$\mathrm{Cu}^{2+}$ & 15 \\
$\mathrm{Fe}^{3+}$ & 15 \\
$\mathrm{~K}^{+}$ & 2000 \\
$\mathrm{Mg}^{2+}$ & 350 \\
$\mathrm{Mn}^{2+}$ & 1000 \\
$\mathrm{Na}^{+}$ & 2000 \\
$\mathrm{~Pb}^{2+}$ & 20 \\
$\mathrm{C}_{2} \mathrm{O}_{4}^{2-}($ oxalate $)$ & 300 \\
$\mathrm{CH}_{3} \mathrm{COO}^{-}$(acetate) & 2000 \\
$\mathrm{C}_{6} \mathrm{H}_{5} \mathrm{O}_{7}{ }^{3-}$ (citrate) & 100 \\
$\mathrm{C}_{4} \mathrm{H}_{4} \mathrm{O}_{6}{ }^{2-}$ (tartrate $)$ & 500 \\
\hline
\end{tabular}

\section{Conclusions}

The procedure has a sensitivity of $0.1 \mathrm{mg} / \mathrm{dm}^{3} \mathrm{NO}_{3}^{-}$in the presence of $20 \mathrm{mg} / \mathrm{dm}^{3}$ of $\mathrm{NO}_{2}^{-}$ions, and allows a large number of analyses simultaneously.

The removal of nitrite with sulfaminic acid is ensured of the value of $\mathrm{pH}$ essential for process, the $\mathrm{Na}_{2} \mathrm{SO}_{4}-$ stable ionic strength in solutions, all reagents having a little impact on waste water sewage and the environment. 
Due to the use of zinc dust and $\mathrm{Na}_{2} \mathrm{SO}_{4}$ it is minimized the cost of the analysis, the level of water pollution from sewage system and the environment, compared to the use of cadmium metal, vanadium and manganese compounds, etc. for nitrates reduction.

The simplicity of the process steps allows of carrying out the analysis of a large number of samples simultaneously, including for evaluation of the error and the standard deviation of nitrate content in the presence of nitrite.

\section{References}

1. Mustea, M.; Boian, I.; Galca, G.; Sandu, M.; Tarita, A.; Zubcov, E.; Sireteanu, D.; Gladchi, V.; Prepelita, A.; Jeleapov, V.; Serenco, L. State of water resources. In: National Report on the Environment State in the Republic of Moldova, 2007-2010. Nova-Imprimi: Chisinau, 2011, pp. 75-80 (in Romanian).

2. Galca, G.; Cunician, L.; Sandu, M. et al. State of water resources. In: National Report on the Environment State in the Republic of Moldova, 2004. Nova-Imprimi: Chisinau, 2005, pp. $48-53$ (in Romanian).

3. Government Decision of Republic of Moldova, 15.08.2007/934, on automated information system establishment, State Register of natural mineral waters, drinking water and bottled soft drinks. Official Monitor no. 131-135, Art. No. 970 (Published: 24.08.2007) (in Romanian).

4. Bol'shova,T.A.; Brykina, G.D.; Garmash, A.V. et al. Fundamentals of analytical chemistry. Akademija: Moscow, 2012; 384 p. (in Russian).

5. Novikov, Iu.V.; Lastocichina, K.O.; Boldina, Z.N. The methods for investigation of reservoirs water quality. Medicina: Moscow, 1990, 321 p. (in Russian).

6. Basarghin, N.N.; Oscotscaia, E.R.; Iuscova, E.Iu.; Rozovschii, Iu.G. Individual concentration and spectrometric determination of nitrate ions in natural and waste waters. Factory laboratory. Diagnostics of Materials, 2006, 72(7), pp. 16-18 (in Russian).

7. Eaton, A.D.; Clesceri, L.S.; Greenberg, A.E.; Eds. Standard methods for the examination of water and wastewater; $20^{\text {th }}$ Ed., American Public Health Association: Washington, 1995, 988 p.

8. Cortas, N.K.; Wakid, N.W. Determination of inorganic nitrate in serum and Urine by a kinetic cadmium-reduction method. Clinical Chemistry, 1990, 36(8), pp. 1440-1443.

9. Schneider, N.R; Yeary, R.A. Measurement of nitrite and nitrate in blood. American Journal of Veterinary Research, 1973, 34, pp. 133-135.

10. Miranda, V.; Espey, M.G; Wink, D.A. A rapid, simple spectrophotometer method for simultaneous detection of nitrate and nitrite. Nitric Oxide, 2001, 5(1), pp. 62-71.

11. Mir, S.A. Extraction of $\mathrm{NO}_{\mathrm{x}}$ and Determination of Nitrate by Acid Reduction in Water, Soil, Excreta, Feed, Vegetables and Plant Materials. Journal of Applied Sciences \& Environmental Management, 2009, 13(3), pp. 57-63.

12. Lozan, R.; Ropot, V.; Sandu, M. Determination of nitrate and nitrite in natural waters. Journal of Water Chemistry and Technology, 1989, 11(2), pp. 120-122 (in Russian).

13. Mir, S.A. An improved zinc reduction method for direct determination of nitrate in presence of nitrite, Asian Journal of Chemistry, 2007, 19(7), pp. 5703-5710.

14. Stanley, J.B.; Bruno, J. Spectrometric determination of nitrate and nitrite in natural water and sea-water. Talanta, 1985, 32(2), pp. 115-118.

15. Marzinzig, M.; Nussler, A.K; Stadler, J.; Marzinzig, E. et al. Improved methods to measure end products of nitric oxide in biological fluids: Nitrite, nitrate, and S-nitrosothiols. Nitric oxide, 1997, 1(2), pp. 177-189.

16. Government Decision of Republic of Moldova, 2013/950, Regulation concerning the collection, treatment and discharge of wastewater into the sewer system and/or bodies of water for urban and rural areas. Official Monitor no. 284-289, Art. No. 1061 (Published: 06.12.2013) (in Romanian).

17. Mir, S.A. A rapid technique for determination of nitrate and nitric acid by acid reduction and diazotization at elevated temperature. Analytica Chimica Acta, 2008, 620(1-2), pp. 183-189.

18. SM SR EN 26777:2006. Water Quality. Determination of nitrite. - Molecular absorption spectrometric method (in Romanian).

19. SM SR ISO 7890-3:2006 Water Quality. Determination of nitrate. Part 3: Spectrometric method using sulfosalicylic acid (in Romanian).

20. Safety data sheet according to 1907/2006/EC, Article 31 (24/09/2013 version 3). http://ec.europa.eu/enterprise/ sectors/chemicals/documents/classification/archives/safety-data-sheet/index_en.htm. 